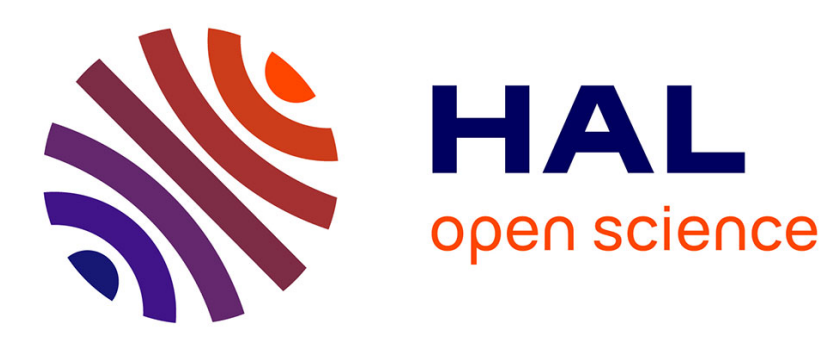

\title{
The Effect of Earnings Management on Debt Maturity: An International Study
}

L ' Effet, Yao Maurice, Yves Mard, Éric Séverin

\section{To cite this version:}

L ' Effet, Yao Maurice, Yves Mard, Éric Séverin. The Effect of Earnings Management on Debt Maturity: An International Study. Comptabilité - Contrôle - Audit, 2020, 26 (2), pp.125. 10.3917/cca.262.0125 . hal-03029366

\section{HAL Id: hal-03029366 https://hal.science/hal-03029366}

Submitted on 28 Nov 2020

HAL is a multi-disciplinary open access archive for the deposit and dissemination of scientific research documents, whether they are published or not. The documents may come from teaching and research institutions in France or abroad, or from public or private research centers.
L'archive ouverte pluridisciplinaire HAL, est destinée au dépôt et à la diffusion de documents scientifiques de niveau recherche, publiés ou non, émanant des établissements d'enseignement et de recherche français ou étrangers, des laboratoires publics ou privés. 


\title{
The Effect of Earnings Management on Debt Maturity: an International Study
}

\section{L'effet de la gestion des résultats sur la maturité de la dette : une étude internationale}

Yao MAURICE*, Yves MARD**, Éric SEVERIN***

* Maître de conférences, Université de Montpellier, Faculté d'économie, MRM

** Professeur des Universités, Université Clermont Auvergne, IAE, CleRMa

*** Professeur des Universités, Université de Lille, IAE-Lille RIME lab, EA 7396

\section{Correspondance :}

Yao Maurice

Maître de conférences

Université de Montpellier

Faculté d'économie Espace

Richter Avenue Raymond

Dugrand - CS 7960634960

Montpellier Cedex 2

yao.maurice@umontpellier.fr

Yves Mard
Professeur des Universités
Université Clermont Auvergne
IAE-CleRMa
11 Boulevard Charles de
Gaulle63000 Clermont-
Ferrand
yves.mard@uca.fr

Éric Séverin

Professeur des Universités

Université de Lille IAE-Lille RIME lab, EA 7396

104 Avenue du Peuple Belge 59000 Lille eric.severin@univ-lille.fr

Remerciements : Les auteurs souhaitent remercier les deux réviseurs anonymes ainsi que la co-rédactrice en chef, Isabelle Martinez, pour leurs remarques pertinentes et constructives. Ils remercient également les réviseurs et discutants des congrès de l'AFC et de l'AAIG.

\begin{abstract}
This paper examines the effect of earnings management on debt maturity and how this relation is influenced by institutional environments. The sample is from 17 European countries of STOXX Europe 600 Index over the 2006-2014 period. We find that firms with high earnings management activities, both the discretionary accruals and real earnings management, are associated with less long-term debt. More importantly, we observe that the negative link between earnings management and long-term debt holds only in countries with weak creditor rights. This suggests that high creditor protection tends to compensate the weakness of borrower's financial reporting quality.
\end{abstract}

Key words: debt maturity, earnings management, creditor rights

\section{Résumé}

Cet article examine l'effet de la gestion des résultats sur la maturité de la dette et comment cette relation est influencée par l'environnement institutionnel. L'échantillon est issu de 17 pays européens de l'indice STOXX Europe 600 sur la période 2006-2014. Nos résultats montrent que la gestion des résultats, aussi bien par les accruals discrétionnaires que par la gestion réelle, a un effet négatif sur la dette à long terme. Plus important encore, nous observons que le lien négatif entre la gestion des résultats et la dette à long terme ne tient que dans les pays à faible protection des créanciers. Ce résultat suggère que la bonne protection des créanciers tend à compenser la faiblesse de la qualité de l'information financière des emprunteurs.

Mots clés : maturité de la dette, gestion des résultats, protection des créanciers 


\section{INTRODUCTION}

Prior literature emphasizes the important role of high financial reporting quality to obtain better debt contracting terms (Ahmed et al. 2002; Francis et al. 2005; Bharath et al. 2008; Costello and Wittenberg-Moerman, 2011). This relationship is based on the idea that financial reporting quality and disclosure are also a means to reduce adverse selection and moral hazard problems by improving contracting and monitoring (Healy and Palepu, 2001). For example, Ahmed et al. (2002); Francis et al. (2005) show that high financial reporting quality contributes to reduce the cost of debt. Bharath et al. (2008) provides evidence that it leads to fewer requirements of collateral. Costello and Wittenberg-Moerman (2011) show that lenders decrease their use of financial covenants when earnings quality is high. Using a sample of small and medium-sized firms in Spain, García-Teruel et al. (2014a) show that firms with higher earnings quality have access to more trade credit from suppliers. García-Teruel et al. (2014b) also analyze the effect of accruals quality on the access of firms to bank debt in a sample of small and medium-sized firms in Spain. The authors find a positive association between accruals quality and bank debt.

If previous empirical research has investigated the role of financial reporting quality in debt contracting terms such as cost of debt, collateral, access to bank debt, there are still few studies on the relationship between financial reporting quality and debt maturity. Examples are Bharath et al. (2008) and García-Teruel et al. (2010) studies. Using accruals quality to measure financial reporting quality, these two authors find that high accounting quality is associated with long-term debt. Thus, in order to extend these previous studies, we examine in our paper, the effect of earnings management ${ }^{1}$ on debt maturity. We further investigate whether creditor rights influence the effect of earnings management on debt maturity.

Since financial statements are an important source of information for lenders, the quality of accounting information impacts the lenders' estimates of future cash flows from which the debt will be repaid (Bharath et al. 2008). Therefore, stringent contract terms for low accounting quality borrowers reflect lenders' compensation for information risk (Easley et al. 2002; Francis et al. 2005; Bharath et al. 2008). In a similar vein, El Ghoul et al. (2016) argue that since corporate misreporting widens lenders' information asymmetry, they respond by more monitoring. For example, by refusing to grant long-term debt. Thus, a high financial reporting quality can contribute to obtain better debt contracting terms such as longer debt maturity. Moreover, Qian and Strahan (2007) and Bae and Goyal (2009) find that stronger 
legal rights result in loans with longer maturities. Accordingly, we investigate whether the negative impact of earnings management on debt maturity depends on creditor rights.

To test our hypothesis, we use a European sample of 3524 observations with STOXX Europe 600 Index between 2006 and 2014. The STOXX Europe 600 Index represents large, mid and small capitalization companies across 17 countries of the European region. Earnings management is frequently used as a measure for information quality in the literature (Bhattacharya et al. 2003; Francis et al. 2005; An et al. 2016). We measure earnings management using two model-estimated earnings management proxies: discretionary accruals and real earnings management activities (Roychowdhury, 2006). We use two measures of discretionary accruals. The first measure is the model developed by Jones (1991) and modified by Dechow et al. (1995). The second measure is the model developed by Kothari et al. (2005). In order to examine whether creditor protection affects the relation between earnings management and debt maturity, we estimate our model for subsamples of strong creditor rights and weak creditor rights.

We find that earnings management has a negative effect on long-term debt in firms' debt maturity structure. This suggests that high financial reporting quality by reducing asymmetry information, contribute to obtain a better debt contracting term such as longer debt maturity. We also find that the negative association between earnings management and long-term debt is attenuated by high creditor protection. This finding suggests that high creditor protection tends to compensate the weakness of borrower's financial reporting quality.

Our main contribution is to study the impact of creditor rights on the relationship between earnings management and debt maturity. Using a European sample, we document that the negative association between earnings management and long-term debt depends on the level of creditor rights. We also extent previous studies (Bharath et al. 2008; García-Teruel et al. 2010) by showing that real management activities impact negatively long-term debt in firms' debt maturity structure. To the best of our knowledge, the relationship between real earnings management activities and debt maturity has never been explored. This is consistent with Roychowdhury (2006) that real activities manipulation can reduce firm value because these activities affects cash flows.

The rest of the paper is organized as follows. Section 1 presents the related literature and our hypothesis. Section 2 describes the research design and the data used in this study. Section 3 presents the results. Finally, we conclude. 


\section{Literature and hypothesis development}

\subsection{The effect of earnings management on debt maturity: literature review}

In this research, we study earnings management through both accruals and real activities manipulations. The link between earnings management and debt maturity has been the subject of little investigation. If we consider earnings management through accruals, this link can be explained by the important role of high financial reporting quality in reducing asymmetry of information. For example, in the context of a code law country, García-Teruel et al. (2010) use Spanish firms to study the relation between accounting quality and debt maturity. They measure accounting quality by the quality of accruals. The result of this study shows that firms with poor accruals quality have shorter debt maturity than firms with good accruals quality. This suggests for the authors that it is worthwhile for firms to improve the quality of their accounting information in order to avoid negative effects of asymmetric information on their access to long-term loans.

Using a sample of loans issued by U.S. public firms in the syndicated loan market, Fang et al. (2016) examine whether borrowing firms' financial statement comparability affects debt contracting. They show that firms with higher comparability take loans with longer maturity, and they are less likely to pledge collateral in loan contracts as compared to firms with lower comparability. Thus, lenders are more willing to offer loans with more lenient terms, such as longer maturity and no collateral requirements.

To the best of our knowledge, the link between real earnings management activities and debt maturity has never been explored in the literature. We therefore extend our analysis to the link between financing conditions and real earnings management. According to Chen et al. (2015), corporate credit risk is higher when real earnings management uncertainty is greater. They consider that real earnings management will influence firm's future cash flow uncertainty and asset value distributions, and therefore will increase credit risk. Kim and Sohn (2013) also consider that real earnings management activities have an impact on the expected level of future cash flows, and therefore the market demands a higher risk premium for these activities. Thus, they observe the cost of capital is positively associated with the extent of real earnings management. Franz et al. (2014) study the impact of proximity to debt covenant violation on earnings management. They find that firms close to violation or technical default of their debt covenants engage in higher levels of real earnings management than far-fromviolation firms. They also show that the result is stronger after the Sarbanes-Oxley Act, and 
for firms with poor credit ratings. These different studies emphasize the potential effect of real earnings management on debt maturity.

\subsection{The impact of creditor rights on the link between earnings management and debt maturity}

Short-maturity debt allows lenders to review their lending decisions more frequently and to restrict borrower flexibility to increase the riskiness of assets (Bae and Goyal, 2009). Thus, creditors use short-term debt to monitor borrowers when accruals quality is low. Indeed, poor accruals quality increases information asymmetry and thereby the riskiness of assets. Creditors can also use short-term debt to monitor borrowers that engage in real earnings management activities. Indeed, real earnings management will influence firm's uncertainty of future cash flows and asset value distributions, and therefore will increase credit risk (Chen et al. 2015; Kim and Sohn 2013).

However, property rights protection affects a lender's incentives to monitor and its ability to recontract (Bae and Goyal, 2009). For instance, Qian and Strahan (2007) and Bae and Goyal (2009) find that strong creditor protection improves borrowers' loan contract terms such as longer loan maturities. Therefore, we argue that in case of lower accounting quality through accruals manipulation, and higher credit risk through real earnings management, strong creditor protection will substitute to short-term debt to monitor borrowers. Indeed, in case of liquidation, creditors with strong protection are more likely to recover their claim compared to creditors with weak protection. This argument is consistent with previous studies. For example, Hong et al. (2016) find that accounting-based covenants are more prevalent in countries with stronger law enforcement and weaker creditor rights. The authors suggest that creditor rights substitute for the use of covenants. Christensen et al. (2016) in the same vein argue that debt contracts are designed to compensate for weaknesses in corporate laws. An et al. (2016) also show that institutional environments influence the effect of earnings management on financial leverage.

Therefore, the lenders response to a poor accounting quality or real earnings management activities such as short-term debt will be less important in countries with strong creditor protection. We expect that the impact of earnings management on debt maturity is lower in the countries with strong creditor rights. Accordingly, we state our hypothesis as follows:

Hypothesis: In the European context, the negative association between earnings management and long-term debt depends on the level of creditor rights. 


\section{Data and methodology}

\subsection{Data}

To investigate the link between earnings management and debt maturity, we collect our data from FACTSET database. We use a European sample of firms with STOXX Europe 600 Index spanning the years 2006 through 2014. The STOXX Europe 600 Index represents large, mid and small capitalization companies across 17 countries of the European region. The initial sample consists of 5400 firm-year observations representing 600 unique firms. Following prior studies on debt maturity, we exclude financial firms (1400) because they have a specific activity. That is, ICB codes between 8000 and 8999 . We also eliminate firms that have missing or incomplete financial data (476). Our final sample consists of 3524 observations covering 17 European countries listed firms for the period 2006-2014.

We have between 374 and 404 observations between 2005 and 2014 with a small standard deviation at 10.57. United Kingdom, France and Germany number of firm-year observations accounts for more than half of our sample. The United Kingdom represents 1,138 observations (32.29\% of our sample), France 614 observations (17.42\% of our sample), and Germany 465 observations (13.20\% of our sample). Finally, 9 ICB sectors represent our sample. Industrials (1,010 observations, i.e., $28.66 \%$ of our sample), Consumer Goods (571 observations, i.e., $16.20 \%$ of our sample) and Consumer Services (622 observations, i.e., $17.65 \%$ of our sample) accounts for more than half of our sample. The sample distribution is presented in Table 1. 
Table 1-Sample distribution

\begin{tabular}{|c|c|c|}
\hline \multicolumn{3}{|c|}{ Panel A: Sample distribution by country } \\
\hline Country & Observation & $\%$ \\
\hline Belgium & 81 & 2.30 \\
\hline Denmark & 131 & 3.72 \\
\hline Finland & 126 & 3.58 \\
\hline France & 614 & 17.42 \\
\hline Germany & 465 & 13.20 \\
\hline Greece & 17 & 0.48 \\
\hline Ireland & 56 & 1.59 \\
\hline Italy & 143 & 4.06 \\
\hline Netherlands & 205 & 5.82 \\
\hline Norway & 79 & 2.24 \\
\hline Austria & 27 & 0.77 \\
\hline Portugal & 27 & 0.77 \\
\hline Spain & 165 & 4.68 \\
\hline Sweden & 250 & 7.09 \\
\hline United Kingdom & 1,138 & 32.29 \\
\hline Total & 3,524 & 100.00 \\
\hline \multicolumn{3}{|c|}{ Panel B: Sample distribution by year } \\
\hline year & Observation & $\%$ \\
\hline 2006 & 374 & 10.61 \\
\hline 2007 & 379 & 10.75 \\
\hline 2008 & 385 & 10.93 \\
\hline 2009 & 389 & 11.04 \\
\hline 2010 & 393 & 11.15 \\
\hline 2011 & 400 & 11.35 \\
\hline 2012 & 398 & 11.29 \\
\hline 2013 & 402 & 11.41 \\
\hline 2014 & 404 & 11.46 \\
\hline Total & 3,524 & 100.00 \\
\hline \multicolumn{3}{|c|}{ Panel C: Sample distribution by ICB sector } \\
\hline Sector & Observation & $\%$ \\
\hline ICB 0001 (Oil \& Gas) & 175 & 4.97 \\
\hline ICB 1000 (Basic Materials) & 338 & 9.59 \\
\hline ICB 2000 (Industrials) & 1,010 & 28.66 \\
\hline ICB 3000 (Consumer Goods) & 571 & 16.20 \\
\hline ICB 4000 (Health Care) & 277 & 7.86 \\
\hline ICB 5000 (Consumer Services) & 622 & 17.65 \\
\hline $\begin{array}{l}\text { ICB } 6000 \\
\text { (Telecommunications) }\end{array}$ & 166 & 4.71 \\
\hline ICB 7000 (Utilities) & 216 & 6.13 \\
\hline ICB 9000 (Technology) & 149 & 4.23 \\
\hline
\end{tabular}




\subsection{Variables measurement}

\subsubsection{Measuring debt maturity}

Following prior research (Demirgurc-Kunt and Maksimovic 1999; García-Teruel et al. 2010; El Ghoul et al. 2016; Ben-Nasr et al. 2015), we measure debt maturity with the ratio of longterm debt maturing in more than one year to total debt. Long-term debt includes private and public financial debt. Total debt includes short and long-term financial debt.

\subsubsection{Measures of earnings management}

We adopt from the literature two model-estimated earnings management proxies: discretionary accruals and real earnings management activities. Discretionary accruals reflect a measure of earnings management by the choices and the implementing rules of the accounting method. We use two measures of discretionary accruals. The first measure (abs_J) is the one developed by Jones (1991) and modified by Dechow et al. (1995) (1). The second measure (abs_Kot) was developed by Kothari et al. (2005) (2). The two models are defined as follows:

$$
\begin{aligned}
& \frac{\mathrm{ACC}_{\mathrm{i}, \mathrm{t}}}{\mathrm{TA}_{\mathrm{i}, \mathrm{t}-1}}=\beta_{1} \frac{1}{\mathrm{TA}_{\mathrm{i}, \mathrm{t}-1}}+\beta_{2} \frac{\Delta \mathrm{REV}_{\mathrm{i}, \mathrm{t}}-\Delta \mathrm{AR}_{\mathrm{i}, \mathrm{t}}}{\mathrm{TA}_{\mathrm{i}, \mathrm{t}-1}}+\beta_{3} \frac{\mathrm{PPE}_{\mathrm{i}, \mathrm{t}}}{\mathrm{TA}_{\mathrm{i}, \mathrm{t}-1}}+\varepsilon_{\mathrm{i}, \mathrm{t}} \\
& \frac{\mathrm{ACC}_{\mathrm{i}, \mathrm{t}}}{\mathrm{TA}_{\mathrm{i}, \mathrm{t}-1}}=\beta_{1} \frac{1}{\mathrm{TA}_{\mathrm{i}, \mathrm{t}-1}}+\beta_{2} \frac{\Delta \mathrm{REV}_{\mathrm{i}, \mathrm{t}}-\Delta \mathrm{CC}_{\mathrm{i}, \mathrm{t}}}{\mathrm{TA}_{\mathrm{i}, \mathrm{t}-1}}+\beta_{3} \frac{\mathrm{PPE}_{\mathrm{i}, \mathrm{t}}}{\mathrm{TA}_{\mathrm{i}, \mathrm{t}-1}}+\beta_{4} \mathrm{ROA}_{\mathrm{i}, \mathrm{t}-1}+\varepsilon_{\mathrm{i}, \mathrm{t}}
\end{aligned}
$$

Where, for fiscal year $\mathrm{t}$ and firm $\mathrm{i}$,

$\mathrm{ACC}_{\mathrm{i}, \mathrm{t}}($ total accruals $)=$ net income $\mathrm{i}_{\mathrm{t}}-$ operating cash flows $_{\mathrm{i}, \mathrm{t}}$

$\mathrm{TA}_{\mathrm{i}, \mathrm{t}-1}=$ total assets from the preceding year

$\Delta \mathrm{REV}_{\mathrm{i}, \mathrm{t}}=$ change in revenues from the preceding year

$\Delta \mathrm{AR}_{\mathrm{i}, \mathrm{t}}=$ change in accounts receivable from the preceding year

$\mathrm{PPE}_{\mathrm{i}, \mathrm{t}}=$ gross value of property, plant, and equipment

$\mathrm{ROA}_{\mathrm{i}, \mathrm{t}-1}=$ return on asset from the preceding year

$\varepsilon_{\mathrm{i}, \mathrm{t}}=$ the error term, is an estimate of discretionary accruals 
Regarding real earnings management, we use Roychowdhury (2006) model. The author suggests that earnings management can take place through three real activities: sales (3), discretionary expenses (4) and production costs (5). First, managers can manipulate sales by offering price discounts or more lenient credit terms, consequently, temporarily increase sales volumes. The result of this manipulation is a lower cash flow from operations in the current period. Second, managers can also reduce discretionary expenditures such as research and development, and advertising. The reduction of discretionary expenses leads to increase earnings. Third, to manage earnings upward, managers can produce more goods than necessary. With higher production levels, the fixed costs per unit will be reducing and thereby increase earnings. The three models used are therefore the following:

$$
\begin{aligned}
& \frac{\mathrm{CFO}_{i, \mathrm{t}}}{\mathrm{TA}_{\mathrm{i}, \mathrm{t}-1}}=\alpha_{1}+\alpha_{2} \frac{1}{\mathrm{TA}_{\mathrm{i}, \mathrm{t}-1}}+\alpha_{3} \frac{\mathrm{S}_{\mathrm{i}, \mathrm{t}}}{\mathrm{TA}_{\mathrm{i}, \mathrm{t}-1}}+\alpha_{4} \frac{\Delta \mathrm{S}_{\mathrm{i}, \mathrm{t}}}{\mathrm{TA} \mathrm{A}_{\mathrm{i}, \mathrm{t}-1}}+\varepsilon_{\mathrm{i}, \mathrm{t}} \\
& \frac{\mathrm{DX}_{\mathrm{i}, \mathrm{t}}}{\mathrm{TA}_{\mathrm{i}, \mathrm{t}-1}}=\alpha_{1}+\alpha_{2} \frac{1}{\mathrm{TA}_{\mathrm{i}, \mathrm{t}-1}}+\alpha_{3} \frac{\mathrm{S}_{\mathrm{i}, \mathrm{t}-1}}{\mathrm{TA}_{\mathrm{i}, \mathrm{t}-1}}+\varepsilon_{\mathrm{i}, \mathrm{t}} \\
& \frac{\mathrm{PROD}_{\mathrm{i}, \mathrm{t}}}{\mathrm{TA}_{\mathrm{i}, \mathrm{t}-1}}=\alpha_{1}+\alpha_{2} \frac{1}{\mathrm{TA}_{\mathrm{i}, \mathrm{t}-1}}+\alpha_{3} \frac{\mathrm{S}_{\mathrm{i}, \mathrm{t}}}{\mathrm{TA}_{\mathrm{i}, \mathrm{t}-1}}+\alpha_{4} \frac{\Delta \mathrm{S}_{\mathrm{i}, \mathrm{t}}}{\mathrm{TA}_{\mathrm{i}, \mathrm{t}-1}}+\alpha_{5} \frac{\Delta \mathrm{S}_{\mathrm{i}, \mathrm{t}-1}}{\mathrm{TA} \mathrm{i}_{\mathrm{i}, \mathrm{t}-1}}+\varepsilon_{\mathrm{i}, \mathrm{t}}
\end{aligned}
$$

Where, for fiscal year $\mathrm{t}$ and firm $\mathrm{i}$,

$\mathrm{CFO}_{\mathrm{i}, \mathrm{t}-1}=$ cash flow from operations

$\mathrm{DX}_{\mathrm{i}, \mathrm{t}}=$ the discretionary expenditures, defined as the sum of advertising expenses, research and development expenses and selling, general and administrative expenses

PROD $_{i, t}=$ the production costs, defined as the sum of cost of goods sold and the change in inventories

$\mathrm{TA}_{\mathrm{i}, \mathrm{t}-1}=$ total assets

$\mathrm{S}_{\mathrm{i}, \mathrm{t}}=$ the sales

$\Delta \mathrm{S}_{\mathrm{i}, \mathrm{t}}=$ change in sales from the preceding year

$\varepsilon_{\mathrm{i}, \mathrm{t}}=$ the error term, is an estimate of abnormal level of cash flow from operations (CFO), discretionary expenses (DX) and production (PROD)

The model coefficients are estimated for each of the nine sectors ${ }^{2}$, as presented in Table 1 . We test our hypothesis using absolute values of both discretionary accruals and real earnings management. The absolute value of these measures allows capturing the level of earnings 
management, whether upward or downward. The greater absolute value of these measures and the fewer is accounting quality.

\subsubsection{Measuring creditor rights}

We use the creditor rights index of Djankov et al. (2007), based on La Porta et al. (1998) creditor rights index in both reorganization and liquidation. The index consists of four indicators: no automatic stay on secured assets; secured creditors first paid; restrictions for going into reorganization; and, management does not stay. Each indicator takes a value of 1 or 0 . Then, the scores are aggregated to create the creditor rights index ranging from 0 (poor creditor protection) to 4 (strong creditor protection).

\subsubsection{Control variables}

We control for firm characteristics that may affect the choice of the debt maturity structure according to debt maturity literature. To control for the effect of credit quality (Diamond 1991), we use the firm's size measured as the logarithm of total asset (SIZE). To capture the nonlinear relation between credit quality and debt maturity predicted by Diamond (1991), we also include size square (SIZEsq).

Following Brockman et al. (2010) we control for financial strength by using Altman's Z score dummy variable $(Z)$. Altman $Z$ score dummy variable takes a value of 1 if the result of Altman Z score is more than 1.81, and zero otherwise. Diamond (1991) also posits that firms with high leverage would face a higher liquidity risk. Therefore, these firms might prefer long-term debt. We control for Leverage (LEV) using the total debt divided by total assets.

Myers (1977) suggests that the underinvestment problem can be eliminated by reducing debt maturity. Indeed, if debt matures before growth options expire, the underinvestment problem will be eliminated. Thus, ceteris paribus, firms with high growth opportunities prefer short term debt. Our measure of growth opportunities is the Market-to-Book ratio (MB). It is equal to the firm value divided by total assets. Myers (1977) also argues that firms with high asset maturities are expected to have larger proportions of long-term debt in their capital structure. Following Datta et al. (2005), we define Asset Maturity (AM) as the sum of proportion of gross property, plant and equipment assets to total assets multiplied by the ratio of gross property, plant and equipment assets to depreciation expenses and proportion of current assets to total assets multiplied by ratio of current assets to cost of goods sold. 
Based on the signalling hypothesis, Flannery (1986) argues that high quality firms prefer to issue short-term debt. To proxy for quality firms, we use Abnormal Earnings (AE), defined as the ratio of change in operating income over the period $[t, t+1]$ to the market value of equity in year $\mathrm{t}$.

Johnson (2003) argues that the probability of repaying debt decreases when firms have greater volatility of cash flows. Thus, firms with highly volatile cash flows might prefer long-term debt. Since greater volatility of cash flows may be associated with greater credit risk, we control for credit risk using the Standard Deviation of Return on Assets (stdROA) over the previous five years. Return on assets is calculated as the ratio of earnings before interest, taxes, depreciation, and amortization to total assets.

Prior literature documents a link between corporate governance and debt maturity (Datta et $a l$. 2005; García-Teruel et al. 2010; Ben-Nasr et al. 2015). Therefore, we control for corporate governance using Datastream Corporate Governance Score (CG). This score measures a company's systems and processes, which ensure that its board members and executives act in the best interests of its long-term shareholders.

\subsection{Model specification}

Debt maturity and leverage are jointly determined because firms likely choose a level of debt and the maturity of that debt simultaneously (Johnson 2003). Thus, ordinary least squares estimation can lead to a biased leverage coefficient. Therefore, to test our hypotheses of a negative relation between earnings management and debt maturity, we estimate a system that models leverage and debt maturity as jointly endogenous. Following Brockman et al. (2010), we use a generalized method of moments (GMM) to estimate the coefficient of our equation system because GMM models improve upon other estimation methods including two-stage least squares (2SLS) and three stage least squares (3SLS) models (El Ghoul et al. 2016). Our two-equation system is specified as follows ${ }^{3}$ :

$$
\begin{aligned}
\text { LEVi, } t=\alpha_{0}+ & \alpha_{1} \text { SIZEi, } t+\alpha_{2} \text { MBi, } t+\alpha_{3} \text { FARi, } t+\alpha_{4} P R O i, t+\alpha_{5} A E i, t+\alpha_{6} \text { stdROAi, } t \\
& +\alpha_{7} \text { OLi, } t+\text { Fixed Effects }+\mu,
\end{aligned}
$$




$$
\begin{gathered}
\text { DMi,t }=\alpha_{0}+\alpha_{1} L E V i, t+\alpha_{2} E M i, t / t-1+\alpha_{3} C G i, t+\alpha_{4} \text { SIZE } i, t+\alpha_{5} \text { SIZEsqi, } t+\alpha_{6} Z i, t \\
+\alpha_{7} M B i, t+\alpha_{8} A M i, t+\alpha_{9} \text { StdROAi, } t+\alpha_{10} A E i, t+\text { Fixed Effects }+\mu,
\end{gathered}
$$

where equation system (6) (7) tests our hypothesis. Dependent variable in the first equation is Leverage (LEV), measured by the total debt divided by total assets. Debt Maturity (DM) is the dependent variable in the second equation. The independent variables are the Logarithm of total assets (SIZE) and its square (SIZEsq); the Market to Book ratio (MB); the Fixed Assets Ratio (FAR), measured as the ratio of net property, plant, and equipment to total assets; the Profitability (PRO), measured as the ratio of earnings before interest, taxes, depreciation, and amortization to total assets; the Abnormal Earnings (AE), defined as the ratio of change in operating income over the period $[t, t+1]$ to the market value of equity in year t; the Asset Return standard deviation (stdROA) is the standard deviation of return on assets over the previous five years; the dummy variable (OL) take the value of 1 for firms with operating loss and 0 otherwise; Earnings Management (EM) represent one of our five measures of earnings management $(t / t-1$ in equation means that we use earnings management in year $\mathrm{t}$ and $\mathrm{t}-1$ ); Datastream Corporate Governance score (CG) measures a company's systems and processes, which ensure that its board members and executives act in the best interests of its long term shareholders; Altman's Z Score $(Z)$ dummy variable takes a value of 1 if the result of Altman $\mathrm{Z}$ score is more than 1.81, and zero otherwise. The Asset Maturity $(\mathrm{AM})$, measured as: (gross property, plant, and equipment /total assets) $\times$ (gross property, plant, and equipment /depreciation expense) + (current assets /total assets) $\times($ current assets /cost of goods sold). Fixed Effects control for country, industry, and year fixed effects. All variables are summarized in the Appendix.

\section{Results}

\subsection{Descriptive statistics and bivariate analysis}

Table 2 (Panel A) show that the average long-term debt proportion in our sample is 75 percent. To test if there is significant difference between long-term debt proportion and creditor rights, we carried out a test of difference of means based on Student's t. In general, we find that the mean of long-term debt proportion is highest when creditor protection is 
strong. This is consistent with Qian and Strahan (2007) and Bae and Goyal (2009) studies. For example, panel B show that this average is 78 percent for United Kingdom firms (strong creditor rights) while for countries with weak creditor rights such as France, the average longterm debt proportion is 71 percent. Panel A shows that, on average, absolute value of discretionary accruals is 3 percent of total asset. The absolute value of real earnings management varies from real activities. It represents 4 percent of total asset for sales manipulation. For discretionary expenses and production costs, the absolute value of real earnings management is around 10 percent of total asset.

Regarding bivariate analysis, Table 3 reports the Pearson matrix correlation of the variables used in the multivariate analyses. The correlation between earnings management and debt maturity is negative and significant at the $1 \%$ level for our five measures of earnings management. In terms of control variables, Leverage, Asset Maturity, Abnormal Earnings, Size and Corporate Governance Score are positively and significantly correlated with debt maturity. While Altman's Z Score dummy variable, Asset Return standard deviation and Market to Book ratio are negatively and significantly correlated with debt maturity. Table 2 presents the descriptive statistics and Table 3, Pearson matrix correlation of our variables.

\section{Table 2 - Descriptive statistics}

Panel A: Descriptive statistics of firm characteristics for the full sample

\begin{tabular}{|l|c|c|c|c|c|c|c|}
\cline { 2 - 8 } \multicolumn{1}{c|}{} & mean & $\mathbf{p 5 0}$ & $\mathbf{m a x}$ & $\mathbf{m i n}$ & $\mathbf{s d}$ & $\mathbf{p 2 5}$ & $\mathbf{p 7 5}$ \\
\hline abs_J & 0.0354 & 0.0234 & 0.3822 & 0.0000 & 0.0410 & 0.0101 & 0.0447 \\
\hline abs_Kot & 0.0354 & 0.0231 & 0.3711 & 0.0000 & 0.0410 & 0.0100 & 0.0448 \\
\hline abs_CFO & 0.0485 & 0.0367 & 0.2964 & 0.0000 & 0.0446 & 0.0170 & 0.0655 \\
\hline abs_PROD & 0.1165 & 0.0865 & 0.9215 & 0.0000 & 0.1122 & 0.0400 & 0.1542 \\
\hline abs_DX & 0.1015 & 0.0699 & 0.9553 & 0.0000 & 0.1111 & 0.0299 & 0.1322 \\
\hline DM & 0.7551 & 0.8305 & 1.0000 & 0.0000 & 0.2408 & 0.6772 & 0.9225 \\
\hline LEV & 0.2648 & 0.2530 & 0.9853 & 0.0000 & 0.1561 & 0.1522 & 0.3627 \\
\hline CG & 62.7228 & 68.9800 & 96.9300 & 1.9700 & 24.2812 & 45.7700 & 83.0300 \\
\hline SIZE & 3.8321 & 3.7933 & 5.5699 & 1.5748 & 0.6371 & 3.3776 & 4.3071 \\
\hline Z & 3.0160 & 2.4165 & 44.3683 & -3.4267 & 2.7333 & 1.6561 & 3.4013 \\
\hline AM & 9.8790 & 6.3140 & 66.9473 & 0.0458 & 10.0053 & 2.5912 & 13.8197 \\
\hline stdROA & 0.0214 & 0.0152 & 0.3880 & 0.0000 & 0.0230 & 0.0088 & 0.0259 \\
\hline AE & 0.1115 & 0.0937 & 2.8219 & -0.7002 & 0.1130 & 0.0667 & 0.1317 \\
\hline MB & 1.1405 & 0.8216 & 11.8404 & 0.0155 & 1.1115 & 0.5027 & 1.3603 \\
\hline
\end{tabular}


Panel B: Descriptive statistics of creditor rights scores, earnings management measures, and long-term debt by country

\begin{tabular}{|l|c|c|c|c|c|c|c|}
\hline \multicolumn{1}{|c|}{ Country } & Creditor rights & DM & abs_J & abs_Kot & abs_CFO & abs_PROD & abs_DX \\
\hline United Kingdom & 4 & 0.7826 & 0.0400 & 0.0398 & 0.0557 & 0.1533 & 0.1298 \\
\hline France & 0 & 0.7172 & 0.0290 & 0.0289 & 0.0444 & 0.1063 & 0.1091 \\
\hline Germany & 3 & 0.7322 & 0.0368 & 0.0380 & 0.0483 & 0.1136 & 0.0985 \\
\hline Belgium & 2 & 0.8206 & 0.0288 & 0.0276 & 0.0424 & 0.0803 & 0.0879 \\
\hline Austria & 3 & 0.7449 & 0.0268 & 0.0259 & 0.0287 & 0.0552 & 0.0484 \\
\hline Denmark & 3 & 0.7164 & 0.0359 & 0.0362 & 0.0612 & 0.1157 & 0.1185 \\
\hline Finland & 1 & 0.7053 & 0.0345 & 0.0355 & 0.0492 & 0.0758 & 0.0661 \\
\hline Ireland & 1 & 0.9116 & 0.0308 & 0.0314 & 0.0802 & 0.1321 & 0.1521 \\
\hline Italy & 2 & 0.7380 & 0.0304 & 0.0300 & 0.0393 & 0.0736 & 0.0752 \\
\hline Netherlands & 3 & 0.7756 & 0.0371 & 0.0376 & 0.0423 & 0.0997 & 0.0835 \\
\hline Norway & 2 & 0.7782 & 0.0486 & 0.0524 & 0.0544 & 0.1150 & 0.0449 \\
\hline Portugal & 1 & 0.7497 & 0.0290 & 0.0278 & 0.0234 & 0.0621 & 0.0492 \\
\hline Spain & 2 & 0.7291 & 0.0328 & 0.0332 & 0.0493 & 0.1000 & 0.0486 \\
\hline Sweden & 1 & 0.7687 & 0.0369 & 0.0357 & 0.0587 & 0.1257 & 0.1017 \\
\hline \multicolumn{2}{|l}{ t-test, United Kingdom versus France } & $0.7687 * * *$ & $0.0369 * * *$ & $0.0357 * * *$ & $0.0587 * * *$ & $0.1257 * * *$ & $0.1017 * *$ \\
& & & & & & & \\
\hline
\end{tabular}

This table presents the descriptive statistics of our sample. The sample includes 3,524 observations between 2006 and 2014 collected from Factset. abs_J is the absolute value of discretionary accruals using the Jones (1991) model and modified by Dechow et $\overline{a l}$. (1995). abs_Kot is the absolute value of discretionary accruals using Kothari et al. (2005) model. abs_CFO, abs_PROD and abs_DX are respectively the absolute value of abnormal level of cash flow from operations, production costs and discretionary expenditures using Roychowdhury (2006) model. DM is the ratio of long-term debt maturing in more than one year to total debt. LEV is total debt divided by total assets. CG is Datastream Corporate Governance Score measures a company's systems and processes, which ensure that its board members and executives act in the best interests of its longterm shareholders. SIZE is the logarithm of total assets. $\mathbf{Z}$ is Altman's Z score. AM is Asset Maturity equal: (gross property, plant, and equipment $/$ total assets) $\times$ (gross property, plant, and equipment $/$ depreciation expense) + (current assets / total assets) $\times$ (current assets / cost of goods sold). stdROA is the standard deviation of Return on Assets over the previous five years. AE is Abnormal Earnings measured as the ratio of change in operating income over the period $[t, t+1]$ to the market value of equity in year $t$. MB is the Market-to-Book ratio equal to the firm value divided by total assets. Creditor rights are the creditor rights protection index outlined in Djankov et al. (2007). 


\section{Table 3 -Pearson matrix correlation}

\begin{tabular}{|c|c|c|c|c|c|c|c|c|c|c|c|c|c|c|}
\hline & DM & abs_J & abs_Kot & abs_CFO & abs_PROD & abs_DX & CG & LEV & SIZE & $\mathrm{Z}$ & $\mathrm{AM}$ & stdROA & $\mathrm{AE}$ & MB \\
\hline $\mathrm{DM}$ & 1.0000 & & & & & & & & & & & & & \\
\hline abs_J & $-0.0995 * * *$ & 1.0000 & & & & & & & & & & & & \\
\hline abs_Kot & $-0.1169 * * *$ & $0.9438 * * *$ & 1.0000 & & & & & & & & & & & \\
\hline abs_CFO & $-0.1400 * * *$ & $0.4182 * * *$ & $0.4236 * * *$ & 1.0000 & & & & & & & & & & \\
\hline abs_PROD & $-0.1860 * * *$ & $0.1574 * * *$ & $0.1662 * * *$ & $0.3287 * * *$ & 1.0000 & & & & & & & & & \\
\hline abs_DX & $-0.1499 * * *$ & $0.0925 * * *$ & $0.0715^{* * *}$ & $0.1914 * * *$ & $0.5322 * * *$ & 1.0000 & & & & & & & & \\
\hline $\mathrm{CG}$ & $0.1090 * * *$ & $-0.0339 *$ & $-0.0344 *$ & $-0.0505 * *$ & $-0.0389 * *$ & $-0.0757 * * *$ & 1.0000 & & & & & & & \\
\hline LEV & $0.3277 * * *$ & $-0.0755 * * *$ & $-0.0700 * * *$ & $-0.1198 * * *$ & $-0.2122 * * *$ & $-0.1212 * * *$ & 0.0069 & 1.0000 & & & & & & \\
\hline Size & $0.0775 * * *$ & $-0.2161 * * *$ & $-0.2038 * * *$ & $-0.2586^{* * *}$ & $-0.2828 * * *$ & $-0.2872 * * *$ & $0.0948 * * *$ & $0.1463^{* * *}$ & 1.0000 & & & & & \\
\hline Z & $-0.1090 * * *$ & $0.0557 * * *$ & $0.0458 * * *$ & $0.1471 * * *$ & $0.1539 * * *$ & $0.1740 * * *$ & $0.0392 * *$ & $-0.3478 * * *$ & $-0.3773 * * *$ & 1.0000 & & & & \\
\hline $\mathrm{AM}$ & $0.1113 * * *$ & $-0.1225 * * *$ & $-0.1209 * * *$ & $-0.2080 * * *$ & $-0.1532 * * *$ & $-0.1927 * * *$ & $0.0414^{* *}$ & $0.1618 * * *$ & $0.1765 * * *$ & $-0.1755 * * *$ & 1.0000 & & & \\
\hline stdROA & $-0.1614 * * *$ & $0.2415^{* * *}$ & $0.2372 * * *$ & $0.2819^{* * *}$ & $0.1621 * * *$ & $0.0938 * * *$ & $-0.0288^{* *}$ & $-0.1750 * * *$ & $-0.2884 * * *$ & $0.1866 * * *$ & -0.0395 & 1.0000 & & \\
\hline $\mathrm{AE}$ & $0.0752 * * *$ & -0.0063 & 0.0013 & 0.0093 & $-0.0468 * * *$ & $-0.0439 * *$ & $0.0492 * * *$ & $0.1875 * * *$ & $0.1254 * * *$ & $-0.1337 * * *$ & $0.0599 * * *$ & -0.0086 & 1.0000 & \\
\hline MB & $-0.2545^{* * *}$ & $0.1087 * * *$ & $0.1033 * * *$ & $0.2539 * * *$ & $0.2372 * * *$ & $0.1651 * * *$ & $-0.0761 * * *$ & $-0.2870 * * *$ & $-0.4526 * * *$ & $0.3818 * * *$ & $-0.1492 * * *$ & $0.3457 * * *$ & $-0.2471 * * *$ & 1.0000 \\
\hline
\end{tabular}

This table provides the correlation matrix. abs_J is the absolute value of discretionary accruals using the Jones (1991) model and modified by Dechow et al. (1995). abs_Kot is the absolute value of discretionary accruals using Kothari et al. (2005) model. abs_CFO, abs_PROD and abs_DX are respectively the absolute value of abnormal level of cash flow from operations, production costs and discretionary expenditures using Roychowdhury (2006) model. DM is the ratio of long-term debt maturing in more than one year to total debt. LEV is total debt divided by total assets. CG is Datastream Corporate Governance Score that measures a company's systems and processes, which ensure that its board members and executives act in the best interests of its long-term shareholders. SIZE and SIZEsq are respectively the logarithm of total assets and its square. Z is Altman's Z score dummy variable. It takes a value of 1 if the result of Altman $Z$ score is more than 1.81, and zero otherwise. AM is Asset Maturity equal: (gross property, plant, and equipment / total assets) $\times$ (gross property, plant, and equipment / depreciation expense) + (current assets / total assets) $\times$ (current assets / cost of goods sold). stdROA is the standard deviation of Return on Assets over the previous five years. AE is Abnormal Earnings measured as the ratio of change in operating income over the period [t, $t+1]$ to the market value of equity in year $t$. MB is the Market-to-Book ratio equal to the firm value divided by total assets. $* * *, * *$, and $*$ denote significance at the $1 \%$, $5 \%$, and $10 \%$ levels, respectively. 


\subsection{The relationship between earnings management and debt maturity}

We present the results of the effect of earnings management on debt maturity structure in a multivariate analysis. Table 4 reports regressions from our model that estimates the debt maturity in the system of simultaneous equations as discussed above. We use the absolute value of each earnings management measures to capture the level of earnings management, whether upward or downward. We use the lagged accruals in our regressions to capture the impact of accruals management that only intervenes at the end of the period. We incorporate control variables that have been shown in previous studies to be important determinants of corporate debt maturity. All our regressions include country, industry, and year fixed effects.

We find that the coefficients of earnings management are significantly negative across our five earnings management measures ${ }^{4}$. We obtain statistical significance at $1 \%$ level for discretionary accruals models (abs_J and abs_Kot). We obtain also statistical significance at 5 $\%$ level for Roychowdhury (2006) production cost model (PROD), $1 \%$ level for cash flow from operations (CFO) model, and statistical significance at $1 \%$ level for discretionary expenses models (DX). The results are also economically significant. For instance, our result indicates that one standard deviation increase in earnings management, leads between to 1.5 $\%$ and $2.5 \%$ decreases in long-term debt proportion to total debt ${ }^{5}$.

Hence, earnings management, both discretionary accruals and real earnings management, have a negative effect on long-term debt in firms' debt maturity structure. This also involves the important role of financial reporting quality to obtain a better debt contracting term such as longer debt maturity. Our study extends previous research (García-Teruel et al. 2010; Bharath et al. 2008) by showing that real earnings management is also associated negatively with long-term debt. Our results suggest that creditor is able to detect real earnings management activities and penalize firms that engage in these activities.

Roychowdhury (2006) suggests that real activities manipulation can reduce firm long-term value because actions taken in the current period to increase earnings can have a negative effect on cash flows in future periods. Lenders estimate borrower's future cash flows to assess their ability to repay. Consequently, by reducing firm value, real activities manipulation tends to decrease its credit quality and thereby impact negatively the debt maturity ${ }^{6}$. This result is consistent with Chen et al. (2015) and Kim and Sohn (2013) who document that real earnings management is associated with uncertainty about future cash flows and higher credit risk. 
Even though earnings management by manipulation of accruals has no direct impact on cash flow (Roychowdhury 2006), the negative association between poor accruals quality and longterm debt reveals the ability of lenders to process and analyze accounting information potentially manipulated by discretionary accruals. Consequently, lenders compensate the risk of weakness in borrower's financial reporting quality by short-term debt to monitor borrowers.

Most of the control variables are statistically significant. Consistent with the literature (Johnson 2003), Leverage (LEV) is positive and highly significant. The size variable (SIZE) and its square (SIZEsq) are positively and negatively related to the debt maturity. This is consistent with the non-linear relationship between debt maturity and credit quality predicted by Diamond (1991). The coefficient of Asset Maturity (AM) is positive and significant. Consistent with Myers's (1977) argument, the coefficient of growth opportunity variable (MB) is negative. The coefficient of financial strength $(\mathrm{Z})$ is positively related to the debt maturity. The coefficient of Corporate Governance score (CG) is positively but insignificant related to the debt maturity. We find that the coefficients of Abnormal Earnings (AE) and Asset Return standard deviation (stdROA) are generally insignificant. Datta et al. (2005) found similar results. 
Table 4 - Long-term debt and earnings management

\begin{tabular}{|c|c|c|c|c|c|}
\hline & $(1)$ & (2) & $(3)$ & (4) & $(5)$ \\
\hline LEV & $\begin{array}{c}0.919 * * * \\
(6.55)\end{array}$ & $\begin{array}{c}0.902 * * * \\
(6.45)\end{array}$ & $\begin{array}{c}1.036 * * * \\
(5.58)\end{array}$ & $\begin{array}{c}0.907 * * * \\
(6.48)\end{array}$ & $\begin{array}{c}0.971 * * * \\
(6.48)\end{array}$ \\
\hline L.abs_J & $\begin{array}{c}-0.377 * * * \\
(-2.76)\end{array}$ & & & & \\
\hline L.abs_Kot & & $\begin{array}{c}-0.410 * * * \\
(-2.97)\end{array}$ & & & \\
\hline abs_CFO & & & $\begin{array}{c}-0.517 * * * \\
(-3.38)\end{array}$ & & \\
\hline abs_PROD & & & & $\begin{array}{c}-0.122 * * \\
(-2.09)\end{array}$ & \\
\hline abs_DX & & & & & $\begin{array}{c}-0.230 * * * \\
(-4.48)\end{array}$ \\
\hline MB & $\begin{array}{c}-0.0317 * * * \\
(-4.03)\end{array}$ & $\begin{array}{c}-0.0308 * * * \\
(-3.92)\end{array}$ & $\begin{array}{c}-0.0381 * * * \\
(-4.28)\end{array}$ & $\begin{array}{c}-0.0304 * * * \\
(-4.21)\end{array}$ & $\begin{array}{c}-0.0321^{* * *} \\
(-4.17)\end{array}$ \\
\hline SIZE & $\begin{array}{c}0.225^{* *} \\
(2.29)\end{array}$ & $\begin{array}{c}0.233 * * \\
(2.38)\end{array}$ & $\begin{array}{c}0.281 * * * \\
(2.69)\end{array}$ & $\begin{array}{c}0.178 * * \\
(2.01)\end{array}$ & $\begin{array}{c}0.166^{*} \\
(1.76)\end{array}$ \\
\hline SIZEsq & $\begin{array}{c}-0.0285^{* *} \\
(-2.39)\end{array}$ & $\begin{array}{c}-0.0296^{* *} \\
(-2.49)\end{array}$ & $\begin{array}{c}-0.0350 * * * \\
(-2.80)\end{array}$ & $\begin{array}{c}-0.0233^{* *} \\
(-2.16)\end{array}$ & $\begin{array}{c}-0.0220^{*} \\
(-1.90)\end{array}$ \\
\hline Z & $\begin{array}{c}0.0709 * * * \\
(4.46)\end{array}$ & $\begin{array}{c}0.0681 * * * \\
(4.28)\end{array}$ & $\begin{array}{c}0.107 * * * \\
(4.93)\end{array}$ & $\begin{array}{c}0.0739 * * * \\
(4.76)\end{array}$ & $\begin{array}{c}0.0827 * * * \\
(5.09)\end{array}$ \\
\hline AM & $\begin{array}{c}0.00106^{* *} \\
(2.45)\end{array}$ & $\begin{array}{c}0.00102 * * \\
(2.36)\end{array}$ & $\begin{array}{c}0.00123^{* *} \\
(2.49)\end{array}$ & $\begin{array}{c}0.00136^{* * *} \\
\quad(3.35)\end{array}$ & $\begin{array}{c}0.00150^{* * *} \\
(3.56)\end{array}$ \\
\hline $\mathrm{CG}$ & $\begin{array}{c}0.000405^{*} \\
(1.69)\end{array}$ & $\begin{array}{c}0.000409^{*} \\
(1.71)\end{array}$ & $\begin{array}{c}0.000179 \\
(0.63)\end{array}$ & $\begin{array}{c}0.000455^{*} \\
\quad(1.96)\end{array}$ & $\begin{array}{c}0.000426^{*} \\
(1.82)\end{array}$ \\
\hline stdROA & $\begin{array}{l}-0.185 \\
(-0.54)\end{array}$ & $\begin{array}{l}-0.181 \\
(-0.53)\end{array}$ & $\begin{array}{l}0.323 \\
(0.78)\end{array}$ & $\begin{array}{c}-0.0716 \\
(-0.23)\end{array}$ & $\begin{array}{l}-0.299 \\
(-0.97)\end{array}$ \\
\hline $\mathrm{AE}$ & $\begin{array}{l}-0.0528 \\
(-1.00)\end{array}$ & $\begin{array}{c}-0.0466 \\
(-0.91)\end{array}$ & $\begin{array}{l}-0.0145 \\
(-0.25)\end{array}$ & $\begin{array}{c}-0.0478 \\
(-0.92)\end{array}$ & $\begin{array}{l}-0.0654 \\
(-1.20)\end{array}$ \\
\hline $\begin{array}{l}\text { Fixed effets } \\
\text { cons }\end{array}$ & $\begin{array}{c}\text { Yes } \\
0.139 \\
(0.66)\end{array}$ & $\begin{array}{c}\text { Yes } \\
0.128 \\
(0.61)\end{array}$ & $\begin{array}{c}\text { Yes } \\
0.0105 \\
(0.04)\end{array}$ & $\begin{array}{c}\text { Yes } \\
0.249 \\
(1.29)\end{array}$ & $\begin{array}{c}\text { Yes } \\
0.279 \\
(1.38)\end{array}$ \\
\hline $\mathrm{R}^{2}$ & 0.170 & 0.173 & 0.158 & 0.172 & 0.157 \\
\hline $\mathrm{N}$ & 2717 & 2709 & 2209 & 3058 & 2892 \\
\hline
\end{tabular}

This table shows results for the two-equation system allowing joint determination of maturity and leverage based on GMM. The number of observations is based on available data for all variables. L.abs_J is the lagged absolute value of discretionary accruals using the Jones (1991) model and modified by Dechow et al. (1995). L.abs_Kot is the lagged absolute value of discretionary accruals using Kothari et al. (2005) model. abs_CFO, abs_PROD and abs_DX are respectively the absolute value of abnormal level of cash flow from operations, production costs and discretionary expenditures using Roychowdhury (2006) model. DM is the ratio of long-term debt maturing in more than one year to total debt. LEV is total debt divided by total assets. CG is Datastream Corporate Governance Score measures a company's systems and processes, which ensure that its board members and executives act in the best interests of its long-term shareholders. SIZE and SIZEsq are respectively the logarithm of total assets and its square. $\mathbf{Z}$ is Altman's $Z$ score dummy variable. It takes a value of 1 if the result of Altman Z score is more than 1.81, and zero otherwise. AM is Asset Maturity equal: (gross property, plant, and equipment / total assets $) \times($ gross property, plant, and equipment / depreciation expense $)+($ current assets / total 
assets $) \times($ current assets / cost of goods sold). stdROA is the standard deviation of Return on Assets over the previous five years. AE is Abnormal Earnings measured as the ratio of change in operating income over the period $[t, t+1]$ to the market value of equity in year $t$. MB is the Market-to-Book ratio equal to the firm value divided by total assets. Fixed effects: All regressions include country, sector, and year fixed effects. ***, **, and

$*$ denote significance at the $1 \%, 5 \%$, and $10 \%$ levels, respectively.

\subsection{Do creditor rights impact the relation between earnings management and debt maturity?}

Table 5 reports the results of regression which examine whether the creditor rights influences the relation between earnings management and debt maturity. We argue that the negative association between earnings management and long-term debt holds only in countries with weak creditor rights. To capture this potential effect, we use the creditor rights index of Djankov et al. (2007), based on La Porta et al. (1998) creditor rights index in both reorganization and liquidation. We estimate our model for subsamples of strong creditor rights (score 4), weak creditor rights (score 0) and medium (score 1 to 3). This analysis contributes to prior research (Bharath et al. 2008; García-Teruel et al. 2010) by examining the impact of creditor protection on the relation between earnings management and debt maturity.

We find that the coefficients of earnings management are significantly negative across our five earnings management measures in countries with weak creditor rights and not significant generally in countries with strong creditor rights. In countries with weak creditor rights, we obtain statistical significance at $5 \%$ level for discretionary accruals models and $1 \%$ level for real earnings management activities with cash flow from operations and discretionary expenditures model. Then, 5\% level for production costs model. We also find that the coefficients of earnings management are significantly negative in countries with medium creditor rights. In general, we obtain statistical significance at $10 \%$ level. However, this relationship is less significant than in countries with weak creditor rights. This implies that the impact of creditor protection on the relation between earnings management and debt maturity is more substantial when creditor rights are strong or weak.

The results are consistent with our hypothesis that the negative association between earnings management and long term debt holds only in countries with weak creditor rights. This implies that high creditor protection tends to attenuate the negative association between earnings management and long-term debt.

Our result suggests that better creditor protection tends to compensate the weakness of borrower's accounting quality. Indeed, in event of default by borrower, the better creditor protection should allow their investments to be found more easily compared with countries 
which provide more protection to debtors. Thus, high creditor protection provides a better confidence for lenders in firms financing. 
Table 5 - Long-term debt, earnings management, and creditor rights

\begin{tabular}{|c|c|c|c|c|c|c|c|c|c|c|}
\hline \multicolumn{6}{|c|}{ Strong creditor rights } & \multicolumn{5}{|c|}{ Weak creditor rights } \\
\hline & $(1)$ & $(2)$ & $(3)$ & (4) & $(5)$ & $(1)$ & $(2)$ & (3) & $(4)$ & $(5)$ \\
\hline LEV & $\begin{array}{c}1.038 * * * \\
(5.15)\end{array}$ & $\begin{array}{c}1.072 * * * \\
(5.28)\end{array}$ & $\begin{array}{c}0.878 * * * \\
(2.63)\end{array}$ & $\begin{array}{c}0.987 * * * \\
(4.80)\end{array}$ & $\begin{array}{c}1.114^{* * *} \\
(4.89)\end{array}$ & $\begin{array}{c}0.531 * * * \\
(2.86)\end{array}$ & $\begin{array}{c}0.455^{* *} \\
(2.37)\end{array}$ & $\begin{array}{c}0.721 * * * \\
(4.24)\end{array}$ & $\begin{array}{c}0.501 * * \\
(2.57)\end{array}$ & $\begin{array}{c}0.677 * * * \\
(3.78)\end{array}$ \\
\hline L.abs_J & $\begin{array}{l}-0.358 \\
(-1.49)\end{array}$ & & & & & $\begin{array}{c}-0.507 * * \\
(-2.26)\end{array}$ & & & & \\
\hline L.abs_Kot & & $\begin{array}{l}-0.381 \\
(-1.58)\end{array}$ & & & & & $\begin{array}{c}-0.617 * * \\
(-2.29)\end{array}$ & & & \\
\hline abs_CFO & & & $\begin{array}{c}-0.539^{*} \\
(-1.93)\end{array}$ & & & & & $\begin{array}{c}-1.284 * * * \\
(-4.29)\end{array}$ & & \\
\hline abs_PROD & & & & $\begin{array}{l}-0.108 \\
(-1.34)\end{array}$ & & & & & $\begin{array}{c}-0.290 * * \\
(-2.06)\end{array}$ & \\
\hline abs_DX & & & & & $\begin{array}{c}-0.159 * * \\
(-1.99)\end{array}$ & & & & & $\begin{array}{c}-0.301 * * * \\
(-4.12)\end{array}$ \\
\hline MB & $\begin{array}{c}-0.0413 * * * \\
(-3.38)\end{array}$ & $\begin{array}{c}-0.0404 * * * \\
(-3.30)\end{array}$ & $\begin{array}{c}-0.0572 * * * \\
(-4.19)\end{array}$ & $\begin{array}{c}-0.0475 * * * \\
(-4.23)\end{array}$ & $\begin{array}{c}-0.0516^{* * *} \\
(-4.13)\end{array}$ & $\begin{array}{c}0.0169 \\
(1.36)\end{array}$ & $\begin{array}{c}0.0131 \\
(1.03)\end{array}$ & $\begin{array}{c}0.0228^{*} \\
(1.86)\end{array}$ & $\begin{array}{c}0.0239^{* *} \\
(2.16)\end{array}$ & $\begin{array}{c}0.0205^{*} \\
(1.77)\end{array}$ \\
\hline SIZE & $\begin{array}{l}0.131 \\
(0.83)\end{array}$ & $\begin{array}{l}0.137 \\
(0.86)\end{array}$ & $\begin{array}{l}0.123 \\
(0.72)\end{array}$ & $\begin{array}{c}0.0178 \\
(0.12)\end{array}$ & $\begin{array}{c}-0.0479 \\
(-0.30)\end{array}$ & $\begin{array}{c}1.225^{* * * *} \\
(4.39)\end{array}$ & $\begin{array}{c}1.265^{* * *} \\
(4.54)\end{array}$ & $\begin{array}{c}1.083 * * * \\
(3.62)\end{array}$ & $\begin{array}{c}1.442 * * * \\
(5.27)\end{array}$ & $\begin{array}{c}1.090 * * * \\
(3.98)\end{array}$ \\
\hline SIZEsq & $\begin{array}{c}-0.0136 \\
(-0.69)\end{array}$ & $\begin{array}{c}-0.0146 \\
(-0.73)\end{array}$ & $\begin{array}{c}-0.0138 \\
(-0.66)\end{array}$ & $\begin{array}{c}0.000195 \\
(0.01)\end{array}$ & $\begin{array}{c}0.00763 \\
(0.39)\end{array}$ & $\begin{array}{c}-0.149 * * * \\
(-4.49)\end{array}$ & $\begin{array}{c}-0.154 * * * \\
(-4.67)\end{array}$ & $\begin{array}{c}-0.133 * * * \\
(-3.71)\end{array}$ & $\begin{array}{c}-0.174 * * * \\
(-5.34)\end{array}$ & $\begin{array}{c}-0.134 * * * \\
(-4.04)\end{array}$ \\
\hline $\mathrm{Z}$ & $\begin{array}{c}0.0641 * * * \\
(2.71)\end{array}$ & $\begin{array}{c}0.0659^{* * *} \\
(2.73)\end{array}$ & $\begin{array}{c}0.0976^{* * *} \\
(2.72)\end{array}$ & $\begin{array}{c}0.0683^{* * *} \\
(3.11)\end{array}$ & $\begin{array}{c}0.0695^{* * *} \\
(3.03)\end{array}$ & $\begin{array}{c}0.00950 \\
(0.42)\end{array}$ & $\begin{array}{c}0.00522 \\
(0.23)\end{array}$ & $\begin{array}{c}0.0676^{* *} \\
(2.51)\end{array}$ & $\begin{array}{l}0.0105 \\
(0.47)\end{array}$ & $\begin{array}{c}0.0408^{* *} \\
(1.97)\end{array}$ \\
\hline $\mathrm{AM}$ & $\begin{array}{c}0.000662 \\
(0.88)\end{array}$ & $\begin{array}{c}0.000563 \\
(0.75)\end{array}$ & $\begin{array}{c}0.000131 \\
(0.19)\end{array}$ & $\begin{array}{c}0.000656 \\
(0.91)\end{array}$ & $\begin{array}{c}0.00104 \\
(1.34)\end{array}$ & $\begin{array}{c}0.00241^{*} \\
(1.76)\end{array}$ & $\begin{array}{c}0.00258^{*} \\
(1.93)\end{array}$ & $\begin{array}{c}0.000918 \\
(0.49)\end{array}$ & $\begin{array}{c}0.00202 \\
(1.63)\end{array}$ & $\begin{array}{c}0.00154 \\
(1.25)\end{array}$ \\
\hline $\mathrm{CG}$ & $\begin{array}{c}-0.000550 \\
(-0.63)\end{array}$ & $\begin{array}{c}-0.000589 \\
(-0.68)\end{array}$ & $\begin{array}{c}0.000772 \\
(0.82)\end{array}$ & $\begin{array}{c}0.0000904 \\
(0.12)\end{array}$ & $\begin{array}{c}0.000478 \\
(0.60)\end{array}$ & $\begin{array}{c}0.000628 \\
(1.37)\end{array}$ & $\begin{array}{c}0.000649 \\
(1.43)\end{array}$ & $\begin{array}{c}-0.0000593 \\
(-0.11)\end{array}$ & $\begin{array}{c}0.000300 \\
(0.62)\end{array}$ & $\begin{array}{c}0.000633 \\
(1.43)\end{array}$ \\
\hline stdROA & $\begin{array}{l}0.464 \\
(0.74)\end{array}$ & $\begin{array}{l}0.466 \\
(0.75)\end{array}$ & $\begin{array}{c}1.472 * * * \\
(2.71)\end{array}$ & $\begin{array}{l}0.763 \\
(1.51)\end{array}$ & $\begin{array}{c}-0.0292 \\
(-0.05)\end{array}$ & $\begin{array}{l}0.439 \\
(0.66)\end{array}$ & $\begin{array}{l}0.303 \\
(0.46)\end{array}$ & $\begin{array}{l}0.0615 \\
(0.09)\end{array}$ & $\begin{array}{l}-0.210 \\
(-0.33)\end{array}$ & $\begin{array}{l}-0.460 \\
(-0.73)\end{array}$ \\
\hline $\mathrm{AE}$ & $\begin{array}{c}-0.0372 \\
(-1.09)\end{array}$ & $\begin{array}{c}-0.0399 \\
(-1.15)\end{array}$ & $\begin{array}{c}-0.0321 \\
(-1.00)\end{array}$ & $\begin{array}{c}-0.0451 \\
(-1.36)\end{array}$ & $\begin{array}{c}-0.0529 \\
(-1.62)\end{array}$ & $\begin{array}{l}0.0283 \\
(0.13)\end{array}$ & $\begin{array}{l}0.0331 \\
(0.16)\end{array}$ & $\begin{array}{c}0.0888 \\
(0.35)\end{array}$ & $\begin{array}{c}0.0471 \\
(0.22)\end{array}$ & $\begin{array}{c}0.0739 \\
(0.34)\end{array}$ \\
\hline $\begin{array}{l}\text { Fixed effets } \\
\text { cons }\end{array}$ & $\begin{array}{l}\text { Yes } \\
0.206 \\
(0.57)\end{array}$ & $\begin{array}{l}\text { Yes } \\
0.187 \\
(0.51)\end{array}$ & $\begin{array}{l}\text { Yes } \\
0.200 \\
(0.55)\end{array}$ & $\begin{array}{l}\text { Yes } \\
0.419 \\
(1.29)\end{array}$ & $\begin{array}{l}\text { Yes } \\
0.542 \\
(1.57)\end{array}$ & $\begin{array}{c}\text { Yes } \\
-1.811^{* * *} \\
(-3.16)\end{array}$ & $\begin{array}{c}\text { Yes } \\
-1.860 * * * \\
(-3.26)\end{array}$ & $\begin{array}{c}\text { Yes } \\
-1.488 * * \\
(-2.51)\end{array}$ & $\begin{array}{c}\text { Yes } \\
-2.227 * * * \\
(-4.07)\end{array}$ & $\begin{array}{c}\text { Yes } \\
-1.504 * * * \\
(-2.77)\end{array}$ \\
\hline $\mathrm{R}^{2}$ & 0.131 & 0.124 & 0.235 & 0.176 & 0.134 & 0.355 & 0.365 & 0.325 & 0.358 & 0.349 \\
\hline $\mathrm{N}$ & 919 & 915 & 712 & 1049 & 937 & 461 & 461 & 377 & 504 & 496 \\
\hline
\end{tabular}


Table 5 (continued)

\begin{tabular}{|c|c|c|c|c|c|}
\hline \multicolumn{6}{|c|}{ Medium creditor rights } \\
\hline & (1) & (2) & (3) & (4) & $(5)$ \\
\hline LEV & $\begin{array}{c}0.842 * * * \\
(5.44)\end{array}$ & $\begin{array}{c}0.844 * * * \\
(5.44)\end{array}$ & $\begin{array}{c}0.820 * * * \\
(3.95)\end{array}$ & $\begin{array}{c}0.786^{* * *} \\
(5.30)\end{array}$ & $\begin{array}{c}0.787 * * * \\
(4.96)\end{array}$ \\
\hline L.abs_J & $\begin{array}{c}-0.280^{*} \\
(-1.73)\end{array}$ & & & & \\
\hline L.abs_Kot & & $\begin{array}{c}-0.313 * * \\
(-2.00)\end{array}$ & & & \\
\hline abs_CFO & & & $\begin{array}{l}-0.295 * \\
(-1.75)\end{array}$ & & \\
\hline abs_PROD & & & & $\begin{array}{c}-0.126^{*} \\
(-1.95)\end{array}$ & \\
\hline abs_DX & & & & & $\begin{array}{c}-0.241 * * * \\
(-3.68)\end{array}$ \\
\hline MB & $\begin{array}{c}-0.0452 * * * \\
(-5.32)\end{array}$ & $\begin{array}{c}-0.0435 * * * \\
(-5.10)\end{array}$ & $\begin{array}{c}-0.0602 * * * \\
(-6.72)\end{array}$ & $\begin{array}{c}-0.0442 * * * \\
(-5.65)\end{array}$ & $\begin{array}{c}-0.0478 * * * \\
(-5.80)\end{array}$ \\
\hline SIZE & $\begin{array}{l}0.160 \\
(1.50)\end{array}$ & $\begin{array}{l}0.169 \\
(1.58)\end{array}$ & $\begin{array}{c}0.201^{*} \\
(1.75)\end{array}$ & $\begin{array}{l}0.104 \\
(1.08)\end{array}$ & $\begin{array}{l}0.101 \\
(1.01)\end{array}$ \\
\hline SIZEsq & $\begin{array}{r}-0.0205 \\
(-1.58)\end{array}$ & $\begin{array}{c}-0.0217^{*} \\
(-1.67)\end{array}$ & $\begin{array}{c}-0.0251^{*} \\
(-1.83)\end{array}$ & $\begin{array}{r}-0.0143 \\
(-1.22)\end{array}$ & $\begin{array}{c}-0.0143 \\
(-1.15)\end{array}$ \\
\hline $\mathrm{Z}$ & $\begin{array}{c}0.0761 * * * \\
\quad(4.00)\end{array}$ & $\begin{array}{c}0.0752 * * * \\
(3.93)\end{array}$ & $\begin{array}{c}0.0933 * * * \\
(3.60)\end{array}$ & $\begin{array}{c}0.0753 * * * \\
(4.20)\end{array}$ & $\begin{array}{c}0.0768^{* * *} \\
\quad(4.12)\end{array}$ \\
\hline AM & $\begin{array}{c}0.00111^{* *} \\
\quad(2.35)\end{array}$ & $\begin{array}{c}0.00106^{* *} \\
(2.25)\end{array}$ & $\begin{array}{c}0.00149 * * * \\
(2.75)\end{array}$ & $\begin{array}{c}0.00145 * * * \\
(3.30)\end{array}$ & $\begin{array}{c}0.00171 * * * \\
(3.77)\end{array}$ \\
\hline $\mathrm{CG}$ & $\begin{array}{c}0.000129 \\
(0.43)\end{array}$ & $\begin{array}{c}0.000114 \\
(0.38)\end{array}$ & $\begin{array}{l}0.0000610 \\
(0.18)\end{array}$ & $\begin{array}{c}0.000208 \\
(0.74)\end{array}$ & $\begin{array}{c}0.000174 \\
(0.61)\end{array}$ \\
\hline stdROA & $\begin{array}{l}-0.170 \\
(-0.45)\end{array}$ & $\begin{array}{l}-0.145 \\
(-0.38)\end{array}$ & $\begin{array}{l}0.225 \\
(0.51)\end{array}$ & $\begin{array}{c}-0.0234 \\
(-0.07)\end{array}$ & $\begin{array}{l}-0.291 \\
(-0.86)\end{array}$ \\
\hline $\mathrm{AE}$ & $\begin{array}{l}-0.0351 \\
(-1.05)\end{array}$ & $\begin{array}{c}-0.0282 \\
(-0.86)\end{array}$ & $\begin{array}{c}-0.00148 \\
(-0.04)\end{array}$ & $\begin{array}{c}-0.0188 \\
(-0.51)\end{array}$ & $\begin{array}{c}-0.0356 \\
(-1.07)\end{array}$ \\
\hline Fixed effets & Yes & Yes & Yes & Yes & Yes \\
\hline cons & $\begin{array}{l}0.288 \\
(1.23) \\
\end{array}$ & $\begin{array}{l}0.270 \\
(1.15) \\
\end{array}$ & $\begin{array}{l}0.239 \\
(0.92) \\
\end{array}$ & $\begin{array}{c}0.435 * * \\
(2.04) \\
\end{array}$ & $\begin{array}{c}0.470 * * \\
(2.13) \\
\end{array}$ \\
\hline $\mathrm{R}^{2}$ & 0.170 & 0.169 & 0.221 & 0.187 & 0.191 \\
\hline $\mathrm{N}$ & 1337 & 1333 & 1120 & 1505 & 1459 \\
\hline
\end{tabular}

Table 5 shows results for the two-equation system allowing joint determination of maturity and leverage based on GMM. The number of observations is based on available data for all variables. L.abs_J is the lagged absolute value of discretionary accruals using the Jones (1991) model and modified by Dechow et al. (1995). L.abs_Kot is the lagged absolute value of discretionary accruals using Kothari et al. (2005) model. abs_CFO, abs_PROD and abs_DX are respectively the absolute value of abnormal level of cash flow from operations, production costs and discretionary expenditures using Roychowdhury (2006) model. DM is the ratio of long-term debt maturing in more than one year to total debt. LEV is total debt divided by total assets. CG is Datastream Corporate Governance Score measures a company's systems and processes, which ensure that its board members and executives act in the best interests of its long-term shareholders. SIZE and SIZEsq are respectively the logarithm of total assets and its square. $\mathbf{Z}$ is Altman's $\mathbf{Z}$ score dummy variable. It takes a value of 1 if the result of Altman Z score is more than 1.81, and zero otherwise. AM is Asset Maturity equal: (gross property, plant, and equipment / total assets) $\times$ (gross property, plant, and equipment / depreciation expense) + (current assets / total assets $) \times($ current assets / cost of goods sold). stdROA is the standard deviation of Return on Assets over the previous five years. AE is Abnormal Earnings measured as the ratio of change in operating income over the 
period [t, t +1$]$ to the market value of equity in year $t$. MB is the Market-to-Book ratio equal to the firm value divided by total assets. Fixed effects: All regressions include sector and year fixed effects. $* * *, * *$, and $*$ denote significance at the $1 \%, 5 \%$, and $10 \%$ levels, respectively.

\subsection{Additional test}

We conduct an additional test to analyse the link between earnings management and debt maturity using the signed measures of earnings management. The signed measures of earnings management allow capturing the level of earnings management upward or downward.

Table 6 and table 7 report regressions from our model that estimates the debt maturity in the system of simultaneous equations as discussed above. We use in table 6 , the negative value of each earnings management measures to capture the level of earnings management downward. In table 7, we use the positive value of each earnings management measures to capture the level of earnings management upward. We also use the lagged accruals in our regressions to capture the impact of accruals management that only intervenes at the end of the period. We incorporate control variables that have been shown in previous studies to be important determinants of corporate debt maturity. All our regressions include country, industry, and year fixed effects.

The results show that for negative value of each earnings management measures, the coefficients of earnings management measures are positive and significant without discretionary expenditures model (table 6).

The negative value of earnings management measures by cash flow from operations (CFO) reveals upward earnings management because sales manipulation is associated with lower cash flow in the current period. We observe that earnings management through sales is positively linked to debt maturity. This result suggests that creditors will consider sales manipulation have a negative impact on cash flow.

The negative value of accruals quality (Jones 1991; Kothari 2005) and earnings managementusing overproduction (PROD), reveals downward earnings management. We observe that downward earnings management is negatively linked to debt maturity. Creditors can consider that downward earnings management reveals uncertainty about future cash flows. Thus, this will impact debt maturity.

For the positive value of each earnings management measures, the coefficients are not significant without cash flow from operations model (table7). The positive value of earnings management measures by cash flow from operations (CFO) reveals downward earnings 
management. This result suggest that downward earnings management is negatively linked to debt maturity.

In general, the analysis of the unsigned measure of earnings management show that downward earnings management is negatively associated with debt maturity. This result holds for four of our five measures of earnings management. The association between upward earnings management and debt maturity is only observed for the sales manipulation measure.

The downward earnings management may reveal the firm's difficulties as reflected in the recording of impairments or provisions. Conversely, the upward earnings management through the accruals has no direct impact on cash flow and would thus have less consequence from the creditors' perspective. However, creditors could penalize the upward earnings management through sales manipulation if this is done at the expense of cash flows. 


\section{Table 6 - Long-term debt and earnings management, using the negative value of earnings management measures}

\begin{tabular}{|c|c|c|c|c|c|}
\hline & (1) & (2) & (3) & (4) & (5) \\
\hline LEV & $\begin{array}{c}1.252 * * * \\
(4.30)\end{array}$ & $\begin{array}{c}1.484 * * * \\
(4.71)\end{array}$ & $\begin{array}{c}0.670 * * * \\
(3.38)\end{array}$ & $\begin{array}{c}1.025 * * * \\
(4.35)\end{array}$ & $\begin{array}{c}0.594 * * * \\
(3.13)\end{array}$ \\
\hline L.J & $\begin{array}{c}0.255^{*} \\
(1.75)\end{array}$ & & & & \\
\hline L.Kot & & $\begin{array}{c}0.360 * * \\
(2.34)\end{array}$ & & & \\
\hline CFO & & & $\begin{array}{c}0.703 * * * \\
(3.48)\end{array}$ & & \\
\hline PROD & & & & $\begin{array}{c}0.305^{* * *} \\
(4.22)\end{array}$ & \\
\hline DX & & & & & $\begin{array}{c}-0.0154 \\
(-0.21)\end{array}$ \\
\hline MB & $\begin{array}{c}-0.0170 \\
(-1.35)\end{array}$ & $\begin{array}{c}-0.00594 \\
(-0.47)\end{array}$ & $\begin{array}{c}-0.0536 * * * \\
(-4.19)\end{array}$ & $\begin{array}{c}-0.0262 * * * \\
(-2.69)\end{array}$ & $\begin{array}{l}-0.0135 \\
(-1.08)\end{array}$ \\
\hline SIZE & $\begin{array}{c}0.362^{* *} \\
(2.35)\end{array}$ & $\begin{array}{l}0.186 \\
(1.19)\end{array}$ & $\begin{array}{c}0.288^{* *} \\
(2.18)\end{array}$ & $\begin{array}{l}0.222^{*} \\
(1.69)\end{array}$ & $\begin{array}{l}0.0599 \\
(0.52)\end{array}$ \\
\hline SIZEsq & $\begin{array}{c}-0.0418 * * \\
(-2.23)\end{array}$ & $\begin{array}{c}-0.0205 \\
(-1.07)\end{array}$ & $\begin{array}{c}-0.0392 * * \\
(-2.51)\end{array}$ & $\begin{array}{c}-0.0272 * \\
(-1.68)\end{array}$ & $\begin{array}{c}-0.0103 \\
(-0.74)\end{array}$ \\
\hline Z & $\begin{array}{c}0.0924 * * * \\
(3.02)\end{array}$ & $\begin{array}{c}0.106^{* * *} \\
(3.17)\end{array}$ & $\begin{array}{c}0.0658^{* * *} \\
(2.97)\end{array}$ & $\begin{array}{c}0.0852^{* * * *} \\
(3.10)\end{array}$ & $\begin{array}{c}0.0383 * \\
(1.86)\end{array}$ \\
\hline $\mathrm{AM}$ & $\begin{array}{c}0.00230^{* * * *} \\
(2.69)\end{array}$ & $\begin{array}{c}0.00240^{* * *} \\
(2.60)\end{array}$ & $\begin{array}{c}0.000560 \\
(0.96)\end{array}$ & $\begin{array}{c}0.000628 \\
(0.87)\end{array}$ & $\begin{array}{c}0.00182 * * * \\
(3.02)\end{array}$ \\
\hline $\mathrm{CG}$ & $\begin{array}{c}-0.000109 \\
(-0.28)\end{array}$ & $\begin{array}{c}-0.0000788 \\
(-0.19)\end{array}$ & $\begin{array}{c}0.000499 \\
(1.35)\end{array}$ & $\begin{array}{c}-0.000103 \\
(-0.26)\end{array}$ & $\begin{array}{c}0.000658^{* *} \\
(2.43)\end{array}$ \\
\hline stdROA & $\begin{array}{l}-0.197 \\
(-0.41)\end{array}$ & $\begin{array}{c}-0.0124 \\
(-0.02)\end{array}$ & $\begin{array}{c}-0.722 * \\
(-1.74)\end{array}$ & $\begin{array}{l}0.195 \\
(0.46)\end{array}$ & $\begin{array}{l}-0.103 \\
(-0.28)\end{array}$ \\
\hline $\mathrm{AE}$ & $\begin{array}{c}-0.0491 \\
(-0.56)\end{array}$ & $\begin{array}{c}-0.0867 \\
(-0.88)\end{array}$ & $\begin{array}{c}-0.00134 \\
(-0.02)\end{array}$ & $\begin{array}{c}-0.0472 \\
(-0.37)\end{array}$ & $\begin{array}{c}-0.0157 \\
(-0.26)\end{array}$ \\
\hline $\begin{array}{l}\text { Fixed effets } \\
\text { cons }\end{array}$ & $\begin{array}{c}\text { Yes } \\
-0.306 \\
(-0.84)\end{array}$ & $\begin{array}{c}\text { Yes } \\
-0.0844 \\
(-0.24)\end{array}$ & $\begin{array}{c}\text { Yes } \\
0.226 \\
(0.76)\end{array}$ & $\begin{array}{l}\text { Yes } \\
0.0511 \\
(0.18)\end{array}$ & $\begin{array}{c}\text { Yes } \\
0.568^{* *} \\
(2.47)\end{array}$ \\
\hline $\mathrm{R}^{2}$ & 0.0632 & . & 0.160 & 0.292 & 0.156 \\
\hline $\mathrm{N}$ & 1222 & 1246 & 1240 & 1414 & 1687 \\
\hline
\end{tabular}

L.J is the lagged negative value of discretionary accruals using the Jones (1991) model and modified by Dechow et al. (1995). L.Kot is the lagged negative value of discretionary accruals using Kothari et al. (2005) model.CFO, PROD and DX are respectively the negative value of abnormal level of cash flow from operations, production costs and discretionary expenditures using Roychowdhury (2006) model. DM is the ratio of longterm debt maturing in more than one year to total debt. LEV is total debt divided by total assets. CG is Datastream Corporate Governance Score measures a company's systems and processes, which ensure that its board members and executives act in the best interests of its long-term shareholders. SIZE and SIZEsq are respectively the logarithm of total assets and its square. $\mathbf{Z}$ is Altman's $Z$ score dummy variable. It takes a value of 1 if the result of Altman $Z$ score is more than 1.81, and zero otherwise. AM is Asset Maturity equal: (gross property, plant, and equipment $/$ total assets $) \times($ gross property, plant, and equipment $/$ depreciation expense $)+$ (current assets / total assets) $\times$ (current assets / cost of goods sold). StdROA is the standard deviation of Return on Assets over the previous five years. AE is Abnormal Earnings measured as the ratio of change in operating income over the period [ $t, t+1]$ to the market value of equity in year $t$. MB is the Market-to-Book ratio equal to the firm value divided by total assets. Fixed effects: All regressions include country, sector, and year fixed effects. $* * *, * *$, and $*$ denote significance at the $1 \%, 5 \%$, and $10 \%$ levels, respectively. 


\section{Table 7 - Long-term debt and earnings management, using the positive value of earnings management measures}

\begin{tabular}{|c|c|c|c|c|c|}
\hline & (1) & (2) & (3) & (4) & $(5)$ \\
\hline LEV & $\begin{array}{c}0.661 * * * \\
(3.78)\end{array}$ & $\begin{array}{c}0.542 * * * \\
(3.24)\end{array}$ & $\begin{array}{c}1.687 * * * \\
(3.34)\end{array}$ & $\begin{array}{c}0.794 * * * \\
(4.72)\end{array}$ & $\begin{array}{c}1.238 * * * \\
(5.63)\end{array}$ \\
\hline L.J & $\begin{array}{l}0.135 \\
(0.81)\end{array}$ & & & & \\
\hline L.Kot & & $\begin{array}{l}0.122 \\
(0.74)\end{array}$ & & & \\
\hline $\mathrm{CFO}$ & & & $\begin{array}{c}-0.320 * \\
(-1.79)\end{array}$ & & \\
\hline PROD & & & & $\begin{array}{l}0.111 \\
(1.57)\end{array}$ & \\
\hline DX & & & & & $\begin{array}{c}-0.0406 \\
(-0.53)\end{array}$ \\
\hline MB & $\begin{array}{c}-0.0390 * * * \\
(-3.64)\end{array}$ & $\begin{array}{c}-0.0398 * * * \\
(-3.54)\end{array}$ & $\begin{array}{c}-0.0277 \\
(-1.56)\end{array}$ & $\begin{array}{c}0.0149 \\
(1.23)\end{array}$ & $\begin{array}{c}-0.0242 * * \\
(-1.98)\end{array}$ \\
\hline SIZE & $\begin{array}{l}0.165 \\
(1.34)\end{array}$ & $\begin{array}{c}0.329 * * * \\
(2.68)\end{array}$ & $\begin{array}{c}0.0228 \\
(0.11)\end{array}$ & $\begin{array}{c}0.347 * * * \\
(3.02)\end{array}$ & $\begin{array}{c}0.336^{* *} \\
(2.10)\end{array}$ \\
\hline SIZEsq & $\begin{array}{c}-0.0236 \\
(-1.58)\end{array}$ & $\begin{array}{c}-0.0435 * * * \\
(-2.92)\end{array}$ & $\begin{array}{c}-0.000783 \\
(-0.03)\end{array}$ & $\begin{array}{c}-0.0437 * * * \\
(-3.19)\end{array}$ & $\begin{array}{c}-0.0376^{*} \\
(-1.90)\end{array}$ \\
\hline Z & $\begin{array}{c}0.0552^{* * * *} \\
\quad(2.72)\end{array}$ & $\begin{array}{c}0.0473 * * \\
(2.40)\end{array}$ & $\begin{array}{c}0.230 * * * \\
(3.09)\end{array}$ & $\begin{array}{c}0.0363 * * \\
(2.07)\end{array}$ & $\begin{array}{c}0.0898 * * * \\
(3.73)\end{array}$ \\
\hline $\mathrm{AM}$ & $\begin{array}{c}0.000530 \\
(0.95)\end{array}$ & $\begin{array}{c}0.000461 \\
(0.85)\end{array}$ & $\begin{array}{c}0.00328 * * * \\
(3.14)\end{array}$ & $\begin{array}{c}0.00229 * * * \\
\quad(4.25)\end{array}$ & $\begin{array}{c}0.00129 * \\
(1.94)\end{array}$ \\
\hline CG & $\begin{array}{c}0.000904 * * * \\
(2.90)\end{array}$ & $\begin{array}{c}0.000956^{* * *} \\
(3.02)\end{array}$ & $\begin{array}{c}-0.000178 \\
(-0.35)\end{array}$ & $\begin{array}{c}0.000692^{* *} \\
\quad(2.44)\end{array}$ & $\begin{array}{c}-0.000147 \\
(-0.36)\end{array}$ \\
\hline stdROA & $\begin{array}{l}0.0497 \\
(0.09)\end{array}$ & $\begin{array}{l}-0.124 \\
(-0.23)\end{array}$ & $\begin{array}{c}1.773 * * * \\
(2.77)\end{array}$ & $\begin{array}{l}-0.247 \\
(-0.50)\end{array}$ & $\begin{array}{c}-0.984 * * \\
(-2.25)\end{array}$ \\
\hline $\mathrm{AE}$ & $\begin{array}{l}-0.0690 \\
(-1.03)\end{array}$ & $\begin{array}{c}-0.0623 \\
(-0.95)\end{array}$ & $\begin{array}{c}-0.297 * \\
(-1.81)\end{array}$ & $\begin{array}{c}-0.0177 \\
(-0.31)\end{array}$ & $\begin{array}{l}-0.139 \\
(-1.28)\end{array}$ \\
\hline $\begin{array}{l}\text { Fixed effets } \\
\text { cons }\end{array}$ & $\begin{array}{c}\text { Yes } \\
0.311 \\
(1.26) \\
\end{array}$ & $\begin{array}{c}\text { Yes } \\
0.0259 \\
(0.10) \\
\end{array}$ & $\begin{array}{c}\text { Yes } \\
0.0817 \\
(0.19) \\
\end{array}$ & $\begin{array}{c}\text { Yes } \\
-0.0631 \\
(-0.25) \\
\end{array}$ & $\begin{array}{c}\text { Yes } \\
-0.194 \\
(-0.57) \\
\end{array}$ \\
\hline $\mathrm{R}^{2}$ & 0.220 & 0.211 & 0.105 & 0.119 & 0.242 \\
\hline $\mathrm{N}$ & 1500 & 1465 & 984 & 1649 & 1209 \\
\hline
\end{tabular}

L.J is the lagged the positive value of discretionary accruals using the Jones (1991) model and modified by Dechow et al. (1995). L.Kot is the lagged positive value of discretionary accruals using Kothari et al. (2005) model.CFO, PROD and DX are respectively the positive value of abnormal level of cash flow from operations, production costs and discretionary expenditures using Roychowdhury (2006) model. DM is the ratio of longterm debt maturing in more than one year to total debt. LEV is total debt divided by total assets. CG is Datastream Corporate Governance Score measures a company's systems and processes, which ensure that its board members and executives act in the best interests of its long-term shareholders. SIZE and SIZEsq are respectively the logarithm of total assets and its square. $\mathbf{Z}$ is Altman's $\mathbf{Z}$ score dummy variable. It takes a value of 1 if the result of Altman $Z$ score is more than 1.81, and zero otherwise. AM is Asset Maturity equal: (gross property, plant, and equipment / total assets $) \times($ gross property, plant, and equipment $/$ depreciation expense $)+$ (current assets / total assets) $\times$ (current assets / cost of goods sold). stdROA is the standard deviation of Return on Assets over the previous five years. AE is Abnormal Earnings measured as the ratio of change in operating income over the period [ $t, t+1]$ to the market value of equity in year $t$. MB is the Market-to-Book ratio equal to the firm value divided by total assets. Fixed effects: All regressions include country, sector, and year fixed effects. $* * *, * *$, and $*$ denote significance at the $1 \%, 5 \%$, and $10 \%$ levels, respectively. 


\section{CONCLUSION}

This paper examines whether creditor rights influence the effect of earnings management on debt maturity. For this purpose, we use a European sample of firms representing 17 countries, with STOXX Europe 600 Index spanning the years 2006 through 2014. We measure earnings management with the model developed by Jones (1991) and modified by Dechow et al. (1995), the model developed by Kothari et al. (2005), and real earnings management by Roychowdhury (2006) model.

We find that earnings management, both discretionary accruals and real earnings management, is associated with less long-term debt consistent with Bharath et al. (2008) and Garcia-Teruel et al. (2010) studies. We also show that the negative relation between earnings management and long-term debt depends on the level of creditor rights. The association between earnings management and debt maturity is more prevalent in countries with weak creditor protection.

This paper adds to the literature by providing interesting evidence on the role of earnings management on debt maturity. The evidence suggests that less earnings management can contribute to obtain better debt contracting terms such as longer debt maturity, although the impact is attenuated by a better creditor protection. This finding suggests that high creditor protection tends to compensate the weakness of borrower's financial information. Thus, high creditor protection provides a better confidence for lenders in firms financing.

Our study adds also to the literature on the link between earnings management and debt maturity by showing that real earnings management activities are associated with less longterm debt. This suggests that creditors are able to detect real earnings management activities and penalize firms that engage in these activities. Indeed, these activities might lead to greater uncertainty about future cash flow.

Using a U.S sample, Bharath et al. (2008) examine how accounting quality, measured by accruals quality, affects the borrower's choice of private debt (bank loans) compared with public debt market (bonds). Their results show that borrowers with poorer accounting quality are more likely to choose private debt. They suggest that banks having superior information access and processing abilities that reduce adverse selection costs for borrowers with poorer accounting quality. In this way, for future research, it could be interesting to distinguish private debt and public debt to investigate the effect of earnings management on debt maturity. Earnings smoothing is a type of earnings management (reducing the earnings 
variance). In our research we focus on the level of earnings management whatever the motivation of this reduction. Then, earnings smoothing takes place over several periods. Therefore, it could be also interesting to investigate whether earnings smoothing affects debt maturity. 


\section{Appendix : Definition of Variables}

\begin{tabular}{|c|c|}
\hline \multicolumn{2}{|r|}{ Dependent variable } \\
\hline Debt Maturity (DM) & ratio of long-term debt maturing in more than one year to total debt \\
\hline \multicolumn{2}{|r|}{ Independent variables } \\
\hline abs_J & $\begin{array}{l}\text { absolute value of discretionary accruals using the Jones (1991) model and modified by } \\
\text { Dechow et al. (1995) }\end{array}$ \\
\hline abs_Kot & absolute value of discretionary accruals using Kothari et al. (2005) model \\
\hline abs_CFO & $\begin{array}{l}\text { absolute value of abnormal level of cash flow from operations using Roychowdhury } \\
\text { (2006) model }\end{array}$ \\
\hline abs_PROD & $\begin{array}{l}\text { absolute value of abnormal level of production costs using Roychowdhury (2006) } \\
\text { model }\end{array}$ \\
\hline abs_DX & $\begin{array}{l}\text { absolute value of abnormal level of discretionary expenditures using Roychowdhury } \\
\text { (2006) model }\end{array}$ \\
\hline Creditor rights & $\begin{array}{l}\text { An index aggregating four powers of secured lenders in bankruptcy, following Djankov } \\
\text { et al. (2007). No automatic stay on secured assets; secured creditors first paid; } \\
\text { restrictions for going into reorganization; and, management does not stay. The index } \\
\text { ranges from } 0 \text { (weak) to } 4 \text { (strong creditor rights) }\end{array}$ \\
\hline \multicolumn{2}{|r|}{ Control variables } \\
\hline LEV & total debt divided by total assets \\
\hline $\mathrm{CG}$ & $\begin{array}{l}\text { Datastream Corporate Governance Score measures a company's systems and processes, } \\
\text { which ensure that its board members and executives act in the best interests of its long } \\
\text { term shareholders. }\end{array}$ \\
\hline SIZE & logarithm of total assets \\
\hline SIZEsq & logarithm of total assets square \\
\hline $\mathrm{Z}$ & $\begin{array}{l}\text { Altman's Z Score calculated as } Z=1.2(\mathrm{X} 1)+1.4(\mathrm{X} 2)+3.3(\mathrm{X} 3)+0.6(\mathrm{X} 4)+1.0 \\
(\mathrm{X} 5) . \text { Where } \mathrm{X} 1=\text { working capital/total assets, } \mathrm{X} 2=\text { retained earnings/total assets, } \mathrm{X} 3= \\
\text { earnings before interest and taxes/total assets, } \mathrm{X} 4=\text { Market Value Equity /book value of } \\
\text { total liabilities, } \mathrm{X} 5=(\text { Sales } / \text { Total Assets }) .\end{array}$ \\
\hline MB & Market-to-Book ratio equal to the firm value divided by total assets \\
\hline $\mathrm{AM}$ & $\begin{array}{l}\text { Asset Maturity equal: (gross property, plant, and equipment / total assets) } \times \text { (gross } \\
\text { property, plant, and equipment / depreciation expense })+(\text { current assets / total assets }) \times \\
\text { (current assets / cost of goods sold). }\end{array}$ \\
\hline stdROA & standard deviation of Return on Assets over the previous five years \\
\hline
\end{tabular}




\section{REFERENCES}

Ahmed, A. S., Billings, B. K., Morton, R. M., Stanford-Harris, M. (2002). The Role of Accounting Conservatism in Mitigating Bondholder-Shareholder Conflicts over Dividend Policy and in Reducing Debt Costs. The Accounting Review, 77(4): 867-890.

An, Z., Li, D., Yu, J. (2016). Earnings management, capital structure, and the role of institutional environments. Journal of Banking \& Finance, 68: 131-152.

Bae, K.-H., Goyal, V.K., (2009). Creditor rights, enforcement and bank loans. The Journal of Finance, 64 (2): 823-860.

Ben-Nasr, H., Boubaker, S., Rouatbi, W. (2015). Ownership structure, control contestability, and corporate debt maturity. Journal of Corporate Finance, (35): 265-285.

Bharath, S. T., Sunder, J., Sunder, S. V. (2008). Accounting Quality and Debt Contracting. Accounting Review, 83(1): 1-28.

Bhattacharya, U., Daouk, H., Welker, M. (2003). The World Price of Earnings Opacity. The Accounting Review, 78(3): 641-678.

Brockman, P., Martin, X., Unlu, E. (2010). Executive Compensation and the Maturity Structure of Corporate Debt. Journal of Finance, 65(3): 1123-1161.

Chen, T.-K., Tseng, Y., \& Hsieh, Y.-T. (2015). Real Earnings Management Uncertainty and Corporate Credit Risk. European Accounting Review, 24(3): 413-440.

Christensen, H. B., Nikolaev, V. V., Wittenberg-Moerman, R. (2016). Accounting Information in Financial Contracting: The Incomplete Contract Theory Perspective. Journal of Accounting Research, 54(2): 397-435.

Costello, A. M., Wittenberg-Moerman, R. (2011). The Impact of Financial Reporting Quality on Debt Contracting: Evidence from Internal Control Weakness Reports. Journal of Accounting Research, 49(1): 97-136.

Datta, S., Iskandar-Datta, M. A. I., Raman, K. (2005). Managerial Stock Ownership and the Maturity Structure of Corporate Debt. Journal of Finance, 60(5): 2333-2350.

Dechow, P. M., Sloan, R. G., Sweeney, A. P. (1995). Detecting Earnings Management. The Accounting Review, 70(2): 193-225.

Demirgüç-Kunt, A., Maksimovic, V. (1999). Institutions, financial markets, and firm debt maturity. Journal of Financial Economics, 54(3): 295-336.

Diamond, D. W. (1991). Debt Maturity Structure and Liquidity Risk. The Quarterly Journal of Economics, 106(3): 709-737.

Djankov, S., C. McLiesh, Shleifer, A. (2007). Private credit in 129 countries. Journal of Financial Economics, 84(2): 299-329.

Easley, D., Hvidkjaer, S., O'Hara, M. (2002). Is Information Risk a Determinant of Asset Returns? The Journal of Finance, 57(5): 2185-2221.

Easley, D., O'hara, M. (2004). Information and the Cost of Capital. The Journal of Finance, 59(4): 1540-6261. 
El Ghoul, S., Guedhami, O., Pittman, J. A., Rizeanu, S. (2016). Cross-Country Evidence on the Importance of Auditor Choice to Corporate Debt Maturity. Contemporary Accounting Research, 33(2): 718-751.

Fang, X., Li, Y., Xin, B., Zhang, W. (2016). Financial Statement Comparability and Debt Contracting: Evidence from the Syndicated Loan Market. Accounting Horizons, 30(2): 277-303.

Flannery, M. J. (1986). Asymmetric Information and Risky Debt Maturity Choice. The Journal of Finance, 41(1): 19-37.

Francis, J., LaFond, R., Olsson, P., Schipper, K. (2005). The market pricing of accruals quality. Journal of Accounting and Economics, 39(2): 295-327.

Franz, D., HassabElnaby, H., \& Lobo, G. (2014). Impact of proximity to debt covenant violation on earnings management. Review of Accounting Studies, 19(1): 473-505.

García-Teruel, P. J., Martínez-Solano, P., Sánchez-Ballesta, J. P. (2010). Accruals Quality and Debt Maturity Structure. Abacus, 46(2): 188-210.

García-Teruel, P. J., Martínez-Solano, P., Sánchez-Ballesta, J. P. (2014a). Supplier Financing and Earnings Quality. Journal of Business Finance \& Accounting, 41(9/10): 11931211.

García-Teruel, P. J., Martínez-Solano, P., Sánchez-Ballesta, J. P. (2014b). The role of accruals quality in the access to bank debt. Journal of Banking \& Finance, 38: 186-193.

Healy, P. M., Palepu, K. G. (2001). Information asymmetry, corporate disclosure, and the capital markets: A review of the empirical disclosure literature. Journal of Accounting and Economics, 31(1-3): 405-440.

Hong, H. A., Hung, M., Zhang, J. (2016). The Use of Debt Covenants Worldwide: Institutional Determinants and Implications on Financial Reporting. Contemporary Accounting Research, 33(2): 644-681.

Johnson, S. A. (2003). Debt Maturity and the Effects of Growth Opportunities and Liquidity Risk on Leverage. Review of Financial Studies, 16(1): 209-236.

Jones, J. J. (1991). Earnings Management During Import Relief Investigations. Journal of Accounting Research, 29(2): 193-228.

Kim, J.-B., \& Sohn, B. C. (2013). Real earnings management and cost of capital. Journal of Accounting \& Public Policy, 32(6): 518-543.

Kothari, S. P., Leone, A. J., Wasley, C. E. (2005). Performance matched discretionary accrual measures. Journal of Accounting and Economics, 39(1): 163-197.

Myers, S. C. (1977). Determinants of corporate borrowing. Journal of Financial Economics, 5(2): 147-175.

$\mathrm{Ng}$, J. (2011). The effect of information quality on liquidity risk. Journal of Accounting and Economics, (5)2: 126-143.

La Porta, R. L., Lopez, x, de, x, Silanes, F., vishny, r. w. (1998). Law and Finance. Journal of Political Economy, 106(6): 1113-1155.

Qian, J., Strahan, P.E., (2007). How laws and institutions shape financial contracts: the case of bank loans. The Journal of Finance, 62 (6): 2803-2834.

Roychowdhury, S. (2006). Earnings management through real activities manipulation. Journal of Accounting and Economics, 42(3): 335-370. 


\section{Notes}

${ }^{1}$ Earnings management is an important proxy for information quality presented by insiders to outsiders ( $\mathrm{Ng}$, 2011).

${ }^{2}$ The model coefficients are also estimated for each of the fifteen countries. Our findings remain unchanged.

${ }^{3} \mathrm{We}$ also estimate this system of equations using two-stage least squares (2SLS). Our findings remain unchanged.

${ }^{4}$ We also exclude 2006 from the regression to evoid confusion between IFRS and PCG periods. Our findings remain unchanched.

${ }^{5}$ For example, we multiply the coefficient estimate of earnings management using Jones modified model in table $4(-0.377)$ by its standard deviation in table $2(0.041)$ to obtain $-1.54 \%$.

${ }^{6}$ Diamond (1991) model predicts that firms with low credit quality are forced to issue short-term debt due to large asymmetric information costs. 
